\title{
Critique of the Political Philosophical Interpretation of King Lear
}

\author{
$\mathrm{Xu}$ Zhen \\ Humanities College \\ Xi'an Technological University \\ Xi' an, China \\ e-mail: arogon@126.com
}

\begin{abstract}
Discussion of Shakespeare's tragedy within political theory has been largely dominated by the followers of Leo Strauss, who tend to read Shakespeare as affirming ancient conceptions of virtue and natural right. Most critics ignored the basic premise which has been hidden behind Lear's behavior of division: the conception of modern nation-state has not been shaped and accepted by most people. We will be found that there is no necessary connection between Lear's division and male heir or the eldest son of the principle of inheritance system. Critics pay more attention to the phenomenon of morality or ethical issues of the dram. They didn't have a good grasp of the problem: the destruction of moral ethics was the direct consequence of the alienation of political power.
\end{abstract}

Keywords-King Lear; Political Philosophy; Love Test; Power Alienation

\section{INTRODUCTION}

Tragedy King Lear has always been considered as the best of all Shakespeare's plays. [1] According to Allan Bloom, political philosophy provides a necessary perspective on the problems of Shakespeare's dramas. He believed that any discipline of modern universities can not enjoy the spiritual wealth left by Shakespeare alone, because the university has not been divided into so many different academic disciplines in the Renaissance, but Shakespeare's thought has exceeded the discipline barriers. Therefore, modern university literature department does not enjoy the privilege of understanding Shakespeare's works. Alan Bloom's interpretation has also received response from literary critics, for example, Kiernan Ryan pointed out that
'Shakespeare's mightiest tragedy is now colonized by most kinds of poststructuralist, new-historicist, cultural-materialist, feminist, and psychoanalytic criticism." [2] We could not deny that Shakespeare's inner world is a universe, although "we know almost nothing factual about the inner life of Shakespeare." [3] According to Harold Bloom, "Shakespeare is the center of the embryo of a world canon, not Western or Eastern and less and less Eurocentric." [4]

\section{THE PREMISE OF DIVIDING THE LAND}

Lear divided his country into three parts and assigned to his daughters by the means of love-test. Both Coleridge and Bradley say that the first scene in King Lear is a nursery tale. Many critics have also opined that Lear is a vain and foolish king, rash in his judgment and incapable of controlling his emotions. Lear learned the emptiness of worldly glory when he has lost his power, at the same time, he began to embrace the love of Cordelia and he realized that his youngest daughter's love is the one true value in his life. [5] So, we could say that the play charts the growth of Lear's wisdom.

According to Harry V. Jaffa, King Lear is the greatest of all Shakespeare's kings, because we could see that the old monarch at the head of a united Britain not merely England, and at peace not only with all domestic factions, but with the outside world as well in the first scene of King Lear, both France and Burgundy are suitors for the hand of Cordelia. [6] Harry V. Jaffa's review was considered to be "turning point in the criticism of King Lear." [7] But it is full of contradictions in Harry V. Jaffa's argument. On the one hand, Lear was a great king. On the other hand, Lear divided the kingdom in order to keep a balance of power, because Lear's problem is complicated by the fact that he had three 
daughters but no son, this is the only way to maintain national unity. We all known that monarchy's highest goal is national unity, but Lear imputed the crime of dividing the kingdom. Lear's actions can be regarded as seeking stability but no unity. Even if Lear is the greatest king, and we admitted that "to perpetuate such a rule is an even greater task than to establish it", [8] obviously, Lear destroyed the reunification but no maintain it, he is just trying to get stability. Harry V. Jaffa's interpretation based on imagination, in his opinion, "a balance of power can be better preserved where there are three distinct forces, no one of which can overmatch the other two, than where there are only two forces." [9] Jaffa's explanation secretly affirmed a premise: the battle between Lear's daughters will inevitably arise. The so-called "number two is for strife and the number three is for unity", the argument seems nonsense. As a father, Lear must known Goneril and Regan's collusion, the balance of power between his daughters can not be sustained at all.

In fact, most critics ignored the basic premise which has been hidden behind Lear's behavior of division: the conception of modern nation-state has not been shaped and accepted by most people. In the context, Lear's dividing is no matter with male heir. Even if there are male heirs, the country will be divided into four parts in accordance with dynasty's tradition. Because "Lear's unification of the kingdom was in part due to his ability to secure the adhesion of the lords of these outlying districts through marriage with the royal house." [10] But in the time of modern nation-state, the concept of unity has been deeply rooted in many people's heart. Dynasty country's sealing system has been exceeded, even if the country has no male heirs. For example, the concept of nation-state has been formed in Elizabeth era, so the queen could not be foolish enough to divide the country.

Lear does not suffer any resistance in the division of the kingdom. For example, Kent and Gloucester pay more attention to the division and its equalities. [11] According to Bradley, Lear's original plan was not as absurd as it has been taken to be. For example, Lear never intended to live with his three daughters in turn, but with Cordelia alone. [12] Anyway, we must see that Lear's original plan is still under the premise of dividing. So we could conclude that the
British is still a feudal dynasty but never a modern nation-state. The judgment is the basic prerequisite of critiquing the drama. Lear is neither stupid nor wisdom, and the question is not the focus of the drama, only the power alienation formed its theme.

\section{THE ALIENATION OF THE POWER}

In the history of western thought, it seems established that Hegel, Ludwig Feuerbach, and Karl Marx were the three thinkers who first gave an explicit elaboration of alienation and whose interpretation is the starting point for all discussions of alienation in present-day philosophy, sociology, and psychology. [13] According to Marx's Economic Manuscripts of 1857-1858, alienation is the necessary development of human society: "Relationships of personal dependence (which originally arise quite spontaneously) are the first forms of society, in which human productivity develops only to a limited extent and at isolated points. Personal independence based upon dependence mediated by things is the second great form, and only in it is a system of general social exchange of matter, a system of universal relations, universal requirements and universal capacities, formed. Free individuality, based on the universal development of the individuals and the subordination of their communal, social productivity, which is their social possession, is the third stage. The second stage creates the conditions for the third. Patriarchal conditions and those of antiquity (likewise feudal ones) therefore decline with the development of trade, luxury, money, exchange value, in the same measure in which modern society grows with them step by step." [14] We need to understand that the second stage is alienation, and alienation creates the conditions for free individuality. Marx's Manuscripts turned into the headstream of western critical theories. His thought was extended to such as politics, economy, culture, morality, psychology, art field by Western Marxist. In one word, alienation has become a universal states, nobody can get rid of the survival of alienation.

Power alienation is the typical problem in King Lear, nobody could resolve the problems and it could not be conquered in a long time. Paul A. Cantor has been concerned 
with the phenomenon, as he said, "Precisely what makes him powerful as a king incapacitates him for seeing the truth about himself and his kingdom". [15] We have to ask why. Cantor believes that there is something dangerous in royal power, but he couldn't explain the reason. He also admitted that Lear's gains in wisdom come at the expense of his initial grandeur and hence his ability to rules, [16] and he couldn't offer the reason again. In fact, in the political field, power alienation is everywhere, and politics is essentially an alienated field. Lear is an old king and he has been holding the supreme power for so many years. The royal power was a tool to perform king's duty. But now the tool became control the king in turn. That is the reason of Lear's arbitrary speech act. In the field of power alienation, Lear had been equivalent to absolute authority, in fact, Lear is just a tool for absolute authority but he couldn't realize the truth. Lear's extreme character was also shaped by power alienation. Lear has lost himself in power alienation. Cordelia's sincerity triggered Lear's hatred, as he said, "Better thou Hadst not been born than not t' have pleased me better". [17] Lear was willing to be flattered by the flattery and refused to face the fact. The flattery could highlight the absoluteness of authority, but sincerity will challenge the absolute authority. Lear became a slave of absolute authority, which is the inescapable result of power alienation.

\section{LEAR'S PAINFUL DECISION}

Why should he have to divide his country by the means of love-test in King Lear? It looks like a childish scheme or an absurd fairy tale. But love-test is actually the most profound thing of the text, which is the foundation of the tragedy. Before love-test, the land has been divided into three in Lear's heart. He needs his daughters give protestations to gratify his hunger for assurances of devotion in public. But we known that love-test was a pretense from its beginning. Love-test is typical "do things with words", we all known that the occasion of the power transfer is very dangerous, Lear has no choice, love-test is the only method he could choose, he has tried his best to maintain the balance of power between his daughters but failed miserably.
The so called abdication is never abandoned the crown in King Lear, he retained the name of king when he divided his coronet to his sons in law. Harry V. Jaffa guessed that Lear might have just delegated his "business" to Cornwall and Albany in the original plan, but never completely gave up power. [18] His greed is the result of power alienation. As Paul A. Cantor said, "When Lear is in power, he is blind to his own limitations, not just out of stupidity, senility, or simple error, but because, as Shakespeare shows, there is something in the very nature of kingship that blinds even and perhaps especially a successful ruler to fundamental truths about his situation. When Lear finally gains access to those truths, it is only through a process that disillusions him about politics in general and shatters the very spirit that made him a commanding figure." [19] Power is so tempting that Lear became its slave. Tool rose as the main body while man gradually lost his rational agent. Even if he offered his power and affairs to heirs, Lear is still on the shadow of power.

Most critics believed that Lear's confession in the wilderness is the manifestation of his realization, he recognized that "Poor naked wretches, whereso'er you are, That bide the pelting of this pitiless storm, How shall your houseless heads and unfed sides, Your looped and windowed raggedness, defend you From seasons such as these?" [20] It seems Lear's wisdom returned again. According to Harold Bloom, Lear is "Shakespeare's most passionate character" [21], the so called passion is actually his performance. The purpose of Lear's "dramatic self" is to make everyone and everything witness a king's tragedy. For example, Cordelia died, Lear said: "Howl, howl, howl! O, you are men of stones!" [22] "Howl" became Lear's glory, all the thing proved Lear's personality. He indulged in pain in the storm in order to obtain the noble sense of morality.

\section{REFERENCES}

[1] Kiernan Ryan, "King Lear", in A Companion to Shakespeare's Works, Volume I: The Tragedies, Richard Dutton and Jean E. Howard, Eds. Malden: Blackwell Publishing Ltd, 2003, p.375, 376.

[2] Kiernan Ryan, "King Lear", in A Companion to Shakespeare's Works, Volume I: The Tragedies, Richard Dutton and Jean E. Howard, Eds. Malden: Blackwell Publishing Ltd, 2003, p.375, 376.

[3] Harold Bloom, The western canon: the books and school of the ages. New York: Harcourt Brace \& Company, 1994, p. 51, 62-63, 68. 
[4] Harold Bloom, The western canon: the books and school of the ages. New York: Harcourt Brace \& Company, 1994, p. 51, 62-63, 68.

[5] Paul A. Cantor, "King Lear: The Tragic Disjunction of Wisdom and Power", in Shakespeare's Political Pageant, Joseph Alulis and Vickie Sullivan, Eds. Lanham: Rowman \& Littlefield Publishers, 1996, p. 189, 191, 191, 192, 199.

[6] Harry V. Jaffa, "The Limits of Politics: An Interpretation of King Lear, Act 1, Scene 1", in The American Political Science Review, vol.51, No.2, 1957, p.405, 406, 411, 412, 409, 413.

[7] Paul A. Cantor, "King Lear: The Tragic Disjunction of Wisdom and Power", in Shakespeare's Political Pageant, Joseph Alulis and Vickie Sullivan, Eds. Lanham: Rowman \& Littlefield Publishers, 1996, p. 189, 191, 191, 192, 199.

[8] Harry V. Jaffa, "The Limits of Politics: An Interpretation of King Lear, Act 1 , Scene 1 ", in The American Political Science Review, vol.51, No.2, 1957, p.405, 406, 411, 412, 409, 413.

[9] Harry V. Jaffa, "The Limits of Politics: An Interpretation of King Lear, Act 1, Scene 1", in The American Political Science Review, vol.51, No.2, 1957, p.405, 406, 411, 412, 409, 413.

[10] Harry V. Jaffa, "The Limits of Politics: An Interpretation of King Lear, Act 1, Scene 1", in The American Political Science Review, vol.51, No.2, 1957, p.405, 406, 411, 412, 409, 413.

[11] William Shakespeare, King Lear. Cambridge: Cambridge University Press, 2008, p. 3, 11, 64, 119.

[12] Harry V. Jaffa, "The Limits of Politics: An Interpretation of King Lear, Act 1, Scene 1", in The American Political Science Review, vol.51, No.2, 1957, p.405, 406, 411, 412, 409, 413.
[13] See G. Petrovit, "Alienation”, in Encyclopedia of Philosophy, Vol. 1, Donald M. Borchert, ed. Detroit: Thomson Gale, 2006, pp. 120-127.

[14] Marx, "Economic Manuscripts of 1857-1858", in Marx \& Engels collected Works, Volume 28, Jack Cohen and James S. Allen, Eds. New York: International Publishers, P.95.

[15] Paul A. Cantor, "King Lear: The Tragic Disjunction of Wisdom and Power", in Shakespeare's Political Pageant, Joseph Alulis and Vickie Sullivan, Eds. Lanham: Rowman \& Littlefield Publishers, 1996, p. 189, 191, 191, 192, 199.

[16] Paul A. Cantor, "King Lear: The Tragic Disjunction of Wisdom and Power", in Shakespeare's Political Pageant, Joseph Alulis and Vickie Sullivan, Eds. Lanham: Rowman \& Littlefield Publishers, 1996, p. 189, 191, 191, 192, 199.

[17] William Shakespeare, King Lear. Cambridge: Cambridge University Press, 2008, p. 3, 11, 64, 119.

[18] Harry V. Jaffa, "The Limits of Politics: An Interpretation of King Lear, Act 1, Scene 1", in The American Political Science Review, vol.51, No.2, 1957, p.405, 406, 411, 412, 409, 413.

[19] Paul A. Cantor, "King Lear: The Tragic Disjunction of Wisdom and Power", in Shakespeare's Political Pageant, Joseph Alulis and Vickie Sullivan, Eds. Lanham: Rowman \& Littlefield Publishers, 1996, p. 189, 191, 191, 192, 199.

[20] William Shakespeare, King Lear. Cambridge: Cambridge University Press, 2008, p. 3, 11, 64, 119.

[21] Harold Bloom, The western canon: the books and school of the ages. New York: Harcourt Brace \& Company, 1994, p. 51, 62-63, 68.

[22] William Shakespeare, King Lear. Cambridge: Cambridge University Press, 2008, p. 3, 11, 64, 119. 